\title{
An inventory of mammals, birds and reptiles along a section of the river and banks of upper Ganges, India
}

\author{
Tawqir Bashir ${ }^{1}$, Sandeep Kumar Behera ${ }^{2}$, Afifullah Khan ${ }^{3}$ \& Parikshit Gautam ${ }^{4}$ \\ ${ }^{1}$ Senior Research Fellow, Wildlife Institute of India, Chandrabani, Dehradun, Uttarakhand 248001, India \\ ${ }^{2}$ Associate Director, River Basins and Biodiversity, ${ }^{4}$ Director, Freshwater and Wetland Division, WWF-India, 172 Lodhi Estate, New \\ Delhi, India \\ ${ }^{3}$ Professor, Department of Wildlife Sciences, Aligarh Muslim University, Aligarh, Uttar Pradesh 202002, India \\ Email: ${ }^{1}$ tbashir@wii.gov.in (corresponding author), ${ }^{2}$ sbehera@wwfindia.net, ${ }^{3}$ afifkhan@rediffmail.com, ${ }^{4}$ pgautam@wwfindia.net
}

\begin{abstract}
A study was conducted to assess faunal diversity along a 165-km stretch of the upper Ganges River between Bijnor and Narora cities, Uttar Pradesh, from January to June 2007. Both river and bank species diversity of reptiles, birds and mammals using a combination of boat surveys, linear walks and random searches were inventoried. Presence of 18 species of mammals, 55 species of birds and 13 species of reptiles were recorded from the river stretch including 16 species of global conservation significance. Maximum encounter rate was observed for little cormorant $(3.160 \pm 0.290)$, macaque $(2.385 \pm 0.442)$ and brown roofed turtle $(1.009 \pm 0.107)$. Our study is an attempt towards generating baseline information on the faunal diversity of the upper Ganges and we recommend exhaustive surveys and regular monitoring of this river stretch through indicator species approach.
\end{abstract}

Keywords: Conservation, encounter rate, faunal diversity, Ganges, monitoring.

Date of publication (online): 26 August 2012

Date of publication (print): 26 August 2012

ISSN 0974-7907 (online) | 0974-7893 (print)

Editor: Rahul Kaul

Manuscript details:

Ms \# 02692

Received 02 February 2011

Final received 08 July 2012

Finally accepted 30 July 2012

Citation: Bashir, T., S.K. Behera, A. Khan \& P. Gautam (2012). An inventory of mammals, birds and reptiles along a section of the river and banks of upper Ganges, India. Journal of Threatened Taxa 4(9): 2900-2910.

Copyright: (c) Tawqir Bashir, Sandeep Kumar Behera, Afifullah Khan \& Parikshit Gautam2012. Creative Commons Attribution 3.0 Unported License. JoTT allows unrestricted use of this article in any medium for non-profit purposes, reproduction and distribution by providing adequate credit to the authors and the source of publication.

Acknowledgements: We thank the Department of Wildlife Sciences, Aligarh Muslim University, Aligarh, for providing the logistic support and facilities necessary for conducting the recent surveys. We are grateful to WWF-India for providing the financial support and their information gathered through previous surveys. We express our gratitude to the Department of Environment and Forests (Narora, Brijghat \& Bijnor) for their official help and support. Last but not the least, we thank our field assistants for their help.

\section{OPEN ACGESS | FREE DOWNLOAD}

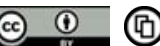

Aquatic ecosystems are critical components of our environment. In addition to being essential contributors to biodiversity and ecological productivity, they also provide a variety of services to human populations (Poff et al. 2002). Rivers, lakes, wetlands and estuaries constituting the freshwater ecosystem alone support about $6 \%$ of the described world species (Hawksworth \& Kalin-Arroyo 1995) and provide habitats consisting of benthic, aquatic, and terrestrial components (FISRWG 2001). Freshwater biodiversity constitutes a valuable natural resource, in economic, cultural, aesthetic, scientific and educational terms (Dudgeon et al. 2006). However, there is an increasing concern worldwide on the loss of aquatic ecosystems and their associated biodiversity (Georges \& Cottingham 2002; Saunders et al. 2002; Cullen 2003), particularly for riverine landscapes (Dunn 2004). Rivers and associated freshwater habitats are among the most threatened ecosystems of the world (Revenga et al. 2005; WWF 2006) due to a wide range of intensive human use and developmental activities. In addition, declines in biodiversity are far greater in fresh waters than in the most affected terrestrial ecosystems (Sala et al. 2000), because inspite of facing varied threats and large scale exploitations, the freshwater hotspots generally receive less management attention than their terrestrial counterparts (Myers et al. 2000). Moreover, knowledge of the diversity of fresh waters is woefully incomplete and the data are insufficient to accurately estimate rates of freshwater biodiversity loss in many regions (Dudgeon et al. 2006).

River Ganges regarded as one of the largest rivers coursing through $2,510 \mathrm{~km}$ from northern to eastern India and acting as a lifeline to the vast Indian plains is well recognised for its enormous cultural and economic significance (Adel 2001). It supports about $8 \%$ of the world's population living in its catchments 
(Newby 1998) and is also a centre of social and religious tradition. Above all, the river is home to a wide variety of life forms ranging from primitive phytoplanktons to highly evolved species such as dolphins, thus signifying its biological and ecological importance. Information on species diversity, abundance and habitat characteristics are key baseline parameters for conservation planning; unfortunately such information is lacking for many river segments of the Ganges.

A stretch of upper Ganges between Rishikesh and Kanpur functions as an ecologically important section because of its hydrological characteristics (Behera 1995). But, due to high regulation of dams, barrages and associated irrigation canals, infrastructure development, water abstraction and pollution, presentday flow of the upper Ganga Basin has decreased by about $2-8 \%$ and such a reduced flow regime also impacts downstream water availability, water quality and riverine ecosystems (Salemme 2007; Behera et al. 2008; Bharati et al. 2011). Within this, a stretch of $165 \mathrm{~km}$ from Bijnor to Narora has been reported to be rich in biodiversity and the only promising habitat for the elusive species such as, Ganges River Dolphin Platanista gangetica gangetica, Smooth-coated Otter Lutrogale perspicillata and Mugger Crocodile Crocodylus palustris in the upper Ganges (Behera 1995; Behera \& Rao 1999; Behera 2002; Bashir et al. 2010a). There is a knowledge gap regarding the faunal assemblage of this stretch and whatever information is available, is in the form of casual records and sightings reported in least accessible formats. With this background, we conducted brief surveys in the stretch in an attempt towards assessing relative abundance and habitat occurrence of species (mammals, birds and reptiles) in the study stretch and along its banks.

\section{Material and Methods}

The study was conducted in a $165-\mathrm{km}$ stretch of upper Ganges, between Bijnor $\left(29^{\circ} 22^{\prime} 12.6^{\prime}\right.$ 'N \& $78^{\circ} 02^{\prime}$ $\left.07.8^{\prime \prime} \mathrm{E}\right)$ and Narora $\left(28^{\circ} 11^{\prime} 28.4^{\prime \prime} \mathrm{N} \& 7^{\circ} 23^{\prime} 48.1^{\prime \prime} \mathrm{E}\right)$ barrages in western Uttar Pradesh, India (Fig. 1), between January and June, 2007. The entire study area had an average width of $200 \mathrm{~m}$ and was generally shallow with only intermittent small stretches of deep water pools. The banks are either sandy or muddy characterized by forest, shrub and grasses.
Surveys were conducted on a motor boat powered by a 15-hp engine at a constant speed of $6 \mathrm{~km} / \mathrm{h}$. Surveys were done between 0600 to $1800 \mathrm{~h}$ which also included frequent halts at the banks generally after every $5 \mathrm{~km}$ on both sides of the river depending on their accessibility. Banks were surveyed up to $1 \mathrm{~km}$ away from the river course through linear walks (1 to $1.5 \mathrm{~km}$ ) along the river, and random searches for wildlife sightings, signs and evidences by a team of five observers (one researcher and four trained field assistants). Further information regarding the presence of various mammal and reptile species was gathered through informal conversations with farmers, fishermen and other people living along the banks. In addition, during boat surveys opportunistic animal sightings on adjacent banks were also recorded. Field recordings were done with naked eye and using $50 \times 10$ binoculars (generally for birds) followed by comparison with field guides (Prater 1971; Ali \& Ripley 1987; Grimmett et al. 2001; Das 2002; Menon 2003; Whitaker \& Captain 2004). Photographs were also taken wherever possible as supporting evidence and later compared with field guides and discussed with species experts for proper identification. We separately calculated encounter rates (number $/ \mathrm{km}$ ) of species recorded during boat surveys and during bank searches and also generated information on their habitat occurrence (river course, islands [small temporary landmasses created in the stretch due to variation in water flow speeds along the banks], riverbeds, bank cliffs, marshlands, agricultural fields and dense forests along banks) based on records and local information. Each survey of the entire stretch along with the bank surveys took about 12-15 days. A total of four boat surveys (two upstream \& two downstream) with an effort of 660 and $116 \mathrm{~km}$ of bank searches were done.

\section{Methodological considerations}

Biodiversity surveys in general are limited by a number of factors. Wetlands being dynamic systems species occurrence and detection are constrained by season and time of the day due to variation in activity levels and behaviour among species (Shields 1977; Rollfinke \& Yahner 1990). Consequently, a combination of boat surveys and ground based bank searches were conducted for estimating relative abundances in terms of encounter rates (separate for each method) as these could act as a useful monitoring 


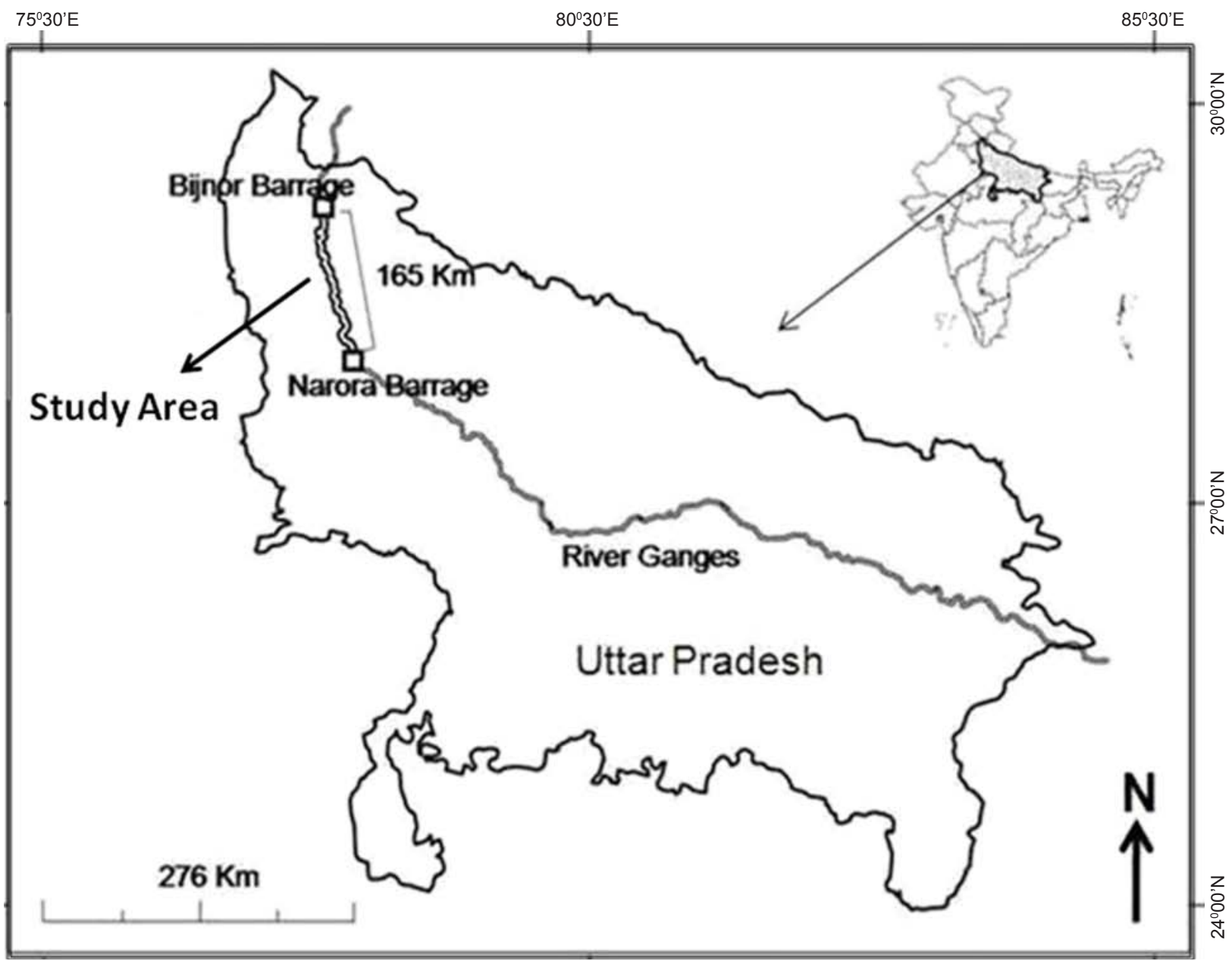

Figure 1. The location of the study area in Uttar Pradesh, India. Source: WWF-India

tool for rapid assessment for a range of species (Anonymous 1998; Kiszka et al. 2004).

We conducted linear surveys along a river stretch, covering 15-20 km and sampling 3-4 segments on each day. Two upstream and two downstream surveys (each survey $165 \mathrm{~km}$ ) were done in this way. Consequently, segments were exposed to sampling over a mixture of daily time periods. Thereafter, we pooled sightings and signs during each complete survey and reported encounter rates of species for the entire river stretch. Similar, technique was used to calculate encounter rates of species recorded during bank searches for a total search/walking effort of $116 \mathrm{~km}$. Our survey method is the most feasible monitoring technique used for wildlife inventories along river stretches and wetlands (Anonymous 1998; Carletti et al. 2004). We invoke that care should be administered in comparing these results with future studies and comparisons should be made only with studies involving similar survey protocols

\section{Results}

\section{Faunal diversity}

We recorded the presence of 18 species of mammals (Table 1), 55 species of birds (Table 2) and 13 species of reptiles (Table 3 ) from the study stretch (aquatic \& terrestrial) including one Critically Endangered, four Endangered, six Vulnerable and five Near Threatened species (IUCN 2010) (Images 1-3). While surveying the banks we also encountered antlers of Swamp Deer Rucervus duvaucelii (Image 1b) and scats of a wild felid species probably that of Fishing Cat Prionailurus viverrinus (Image 1e). Among mammals the maximum encounter rate (individuals $/ \mathrm{km} \pm$ Standard Error) was observed for macaque $(2.385 \pm 0.442)$ followed by Jackal $(0.478 \pm 0.153)$ and Ganges River Dolphin $(0.24 \pm 0.061)$, while minimum was for the Fishing Cat $(0.025 \pm 0.012[$ signs $/ \mathrm{km}])$. In case of birds maximum 
Table 1. List of mammalian species recorded along upper Ganges and its banks.

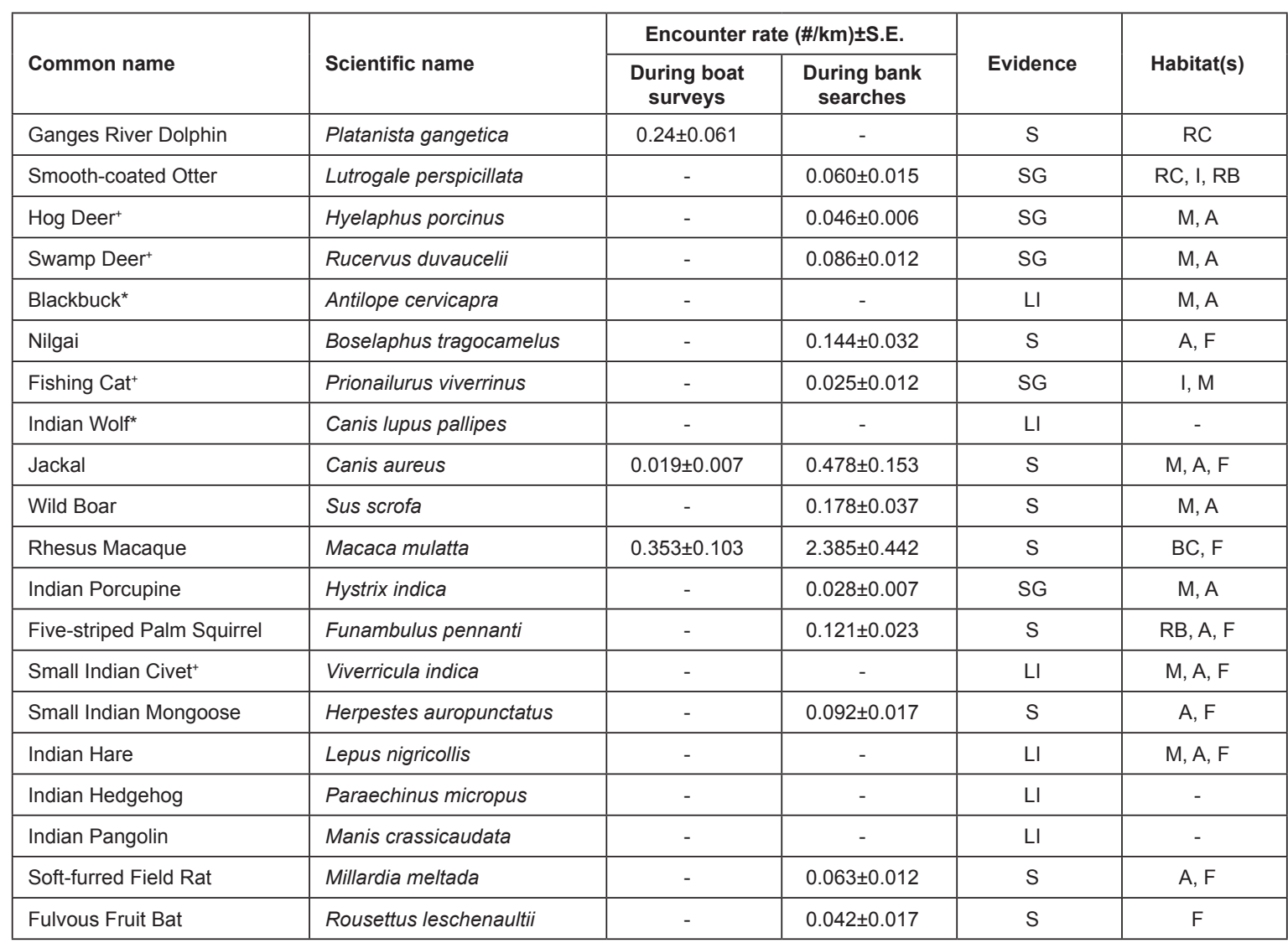

* Species reported by Behera (1995) but not recorded in the present surveys; + New additions to the Isit

$\mathrm{S}=$ Sighting, $\mathrm{SG}=$ Signs, $\mathrm{LI}=$ Local information; $\mathrm{RC}=$ river course, $\mathrm{I}=$ islands, $\mathrm{RB}=$ riverbeds, $\mathrm{BC}=$ bank cliffs, $\mathrm{M}=$ marshlands, $\mathrm{A}=$ agricultural fields $\mathrm{F}=$ dense forests along banks.

Table 2. List of avian species recorded along upper Ganges and its banks.

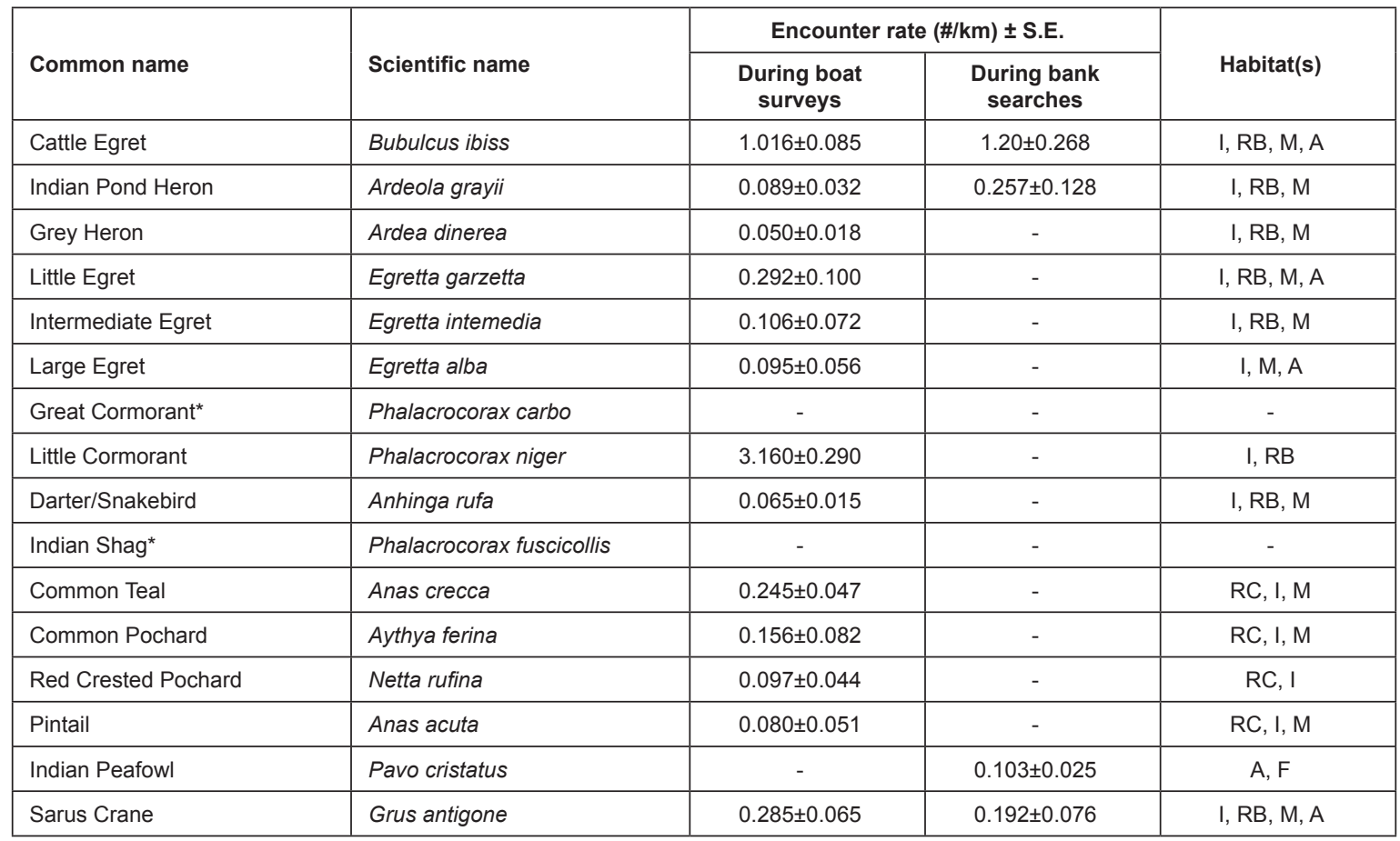




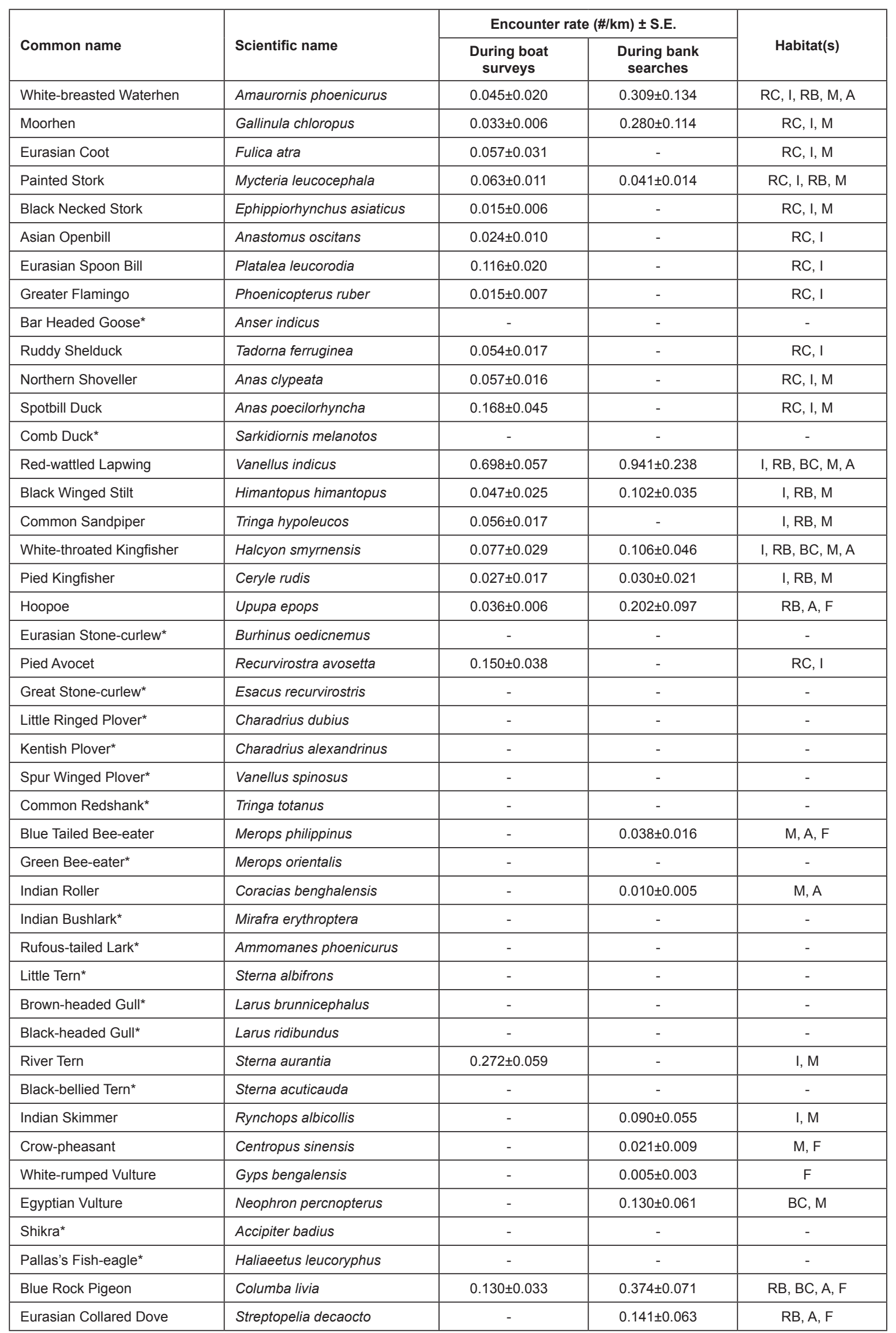




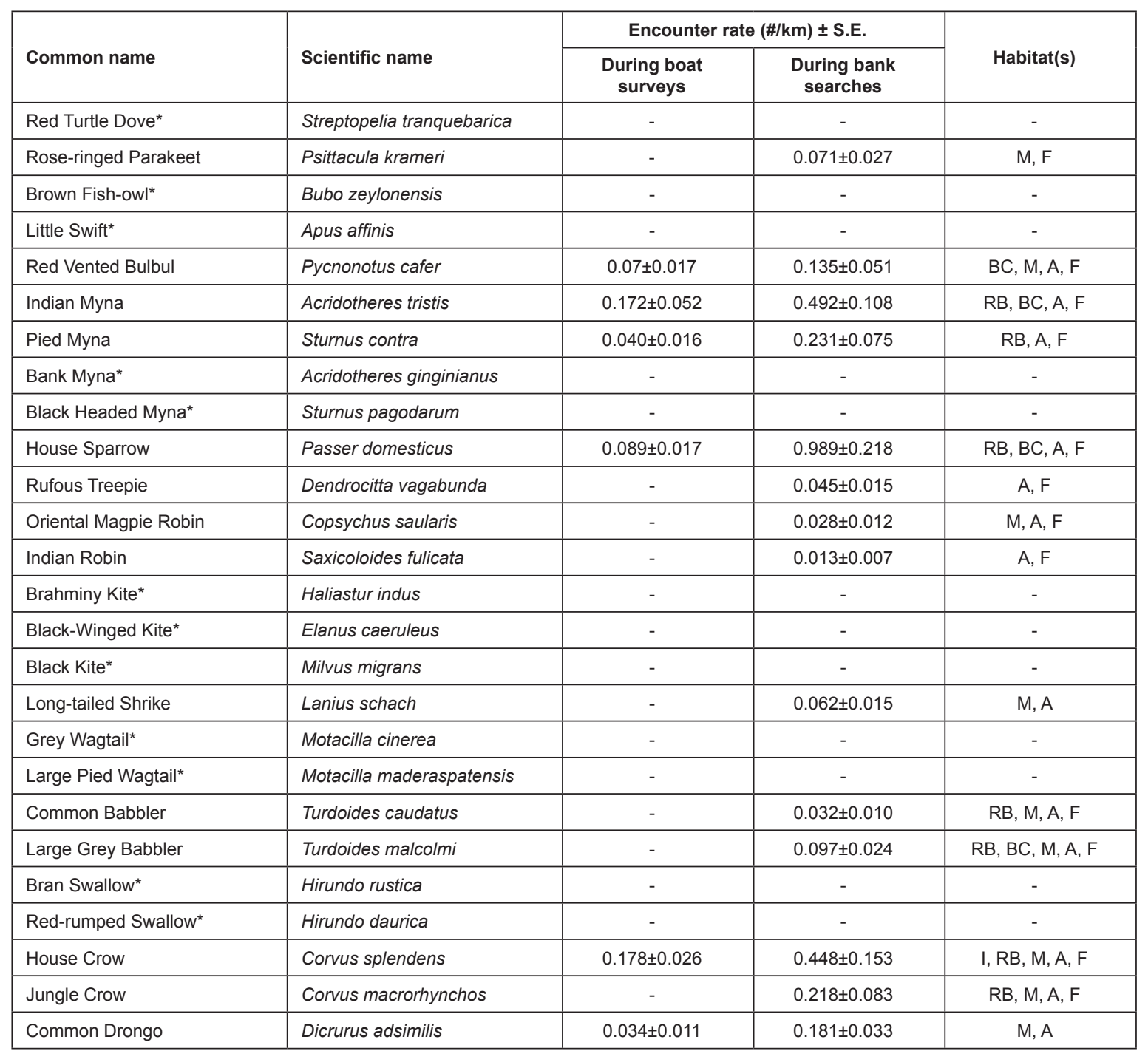

*Species reported by Behera (1995) but not recorded in the present surveys

$\mathrm{RC}=$ river course, $\mathrm{I}=$ islands, $\mathrm{RB}=$ riverbeds, $\mathrm{BC}=$ bank cliffs, $\mathrm{M}=$ marshlands, $\mathrm{A}=$ agricultural fields, $\mathrm{F}=$ dense forests along banks .

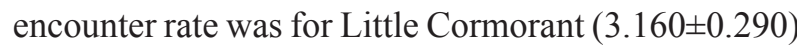
and minimum for Indian White-rumped Vulture Gyps bengalensis $(0.005 \pm 0.003)$. While among reptiles maximum encounter rate was observed for Brown Roofed Turtle (1.009 \pm 0.107$)$ and minimum for Indian Cobra $(0.011 \pm 0.011)$, respectively. The information on the habitat occurrence of mammal species depicted that more than $50 \%$ of species occurred in agricultural fields, dense forests along banks as well as in marshlands while just $12 \%$ occurred in river course, islands and river beds. In case of birds more than $60 \%$ species were encountered in marshlands and islands, and more than $30 \%$ in agricultural fields, river beds, in dense forests along banks as well as in river courses, while only $14 \%$ were encountered in bank cliffs. In addition, more that $50 \%$ of the reptile species were encountered in river beds, agricultural fields, marshlands and dense forests along banks, while more than $30 \%$ in islands and river courses and only $15 \%$ in bank cliffs. Interestingly, more than $80 \%$ of the snake species were encountered in agricultural fields.

Besides this, we encountered carcasses of Indian Monitor Lizard Varanus benghalensis with fatal wounds (Image 1a) and Swamp Deer with cut antlers (Image 1c). We also found entangled Peacock Soft Shell Turtle Nilssonia hurum (Image 3b) in one of the permanently laid fishing nets, recovered antlers of Swamp Deer and Hog Deer Heylaphus porcinus (Image 1d) and rescued a live specimen of Indian Roofed Turtle from local farmers, who superstitiously 
Table 3 List of reptilian species recorded along upper Ganges and its banks.

\begin{tabular}{|c|c|c|c|c|}
\hline \multirow[b]{2}{*}{ Common name } & \multirow[b]{2}{*}{ Scientific name } & \multicolumn{2}{|c|}{ Encounter rate $(\# / \mathbf{k m}) \pm$ S.E. } & \multirow[b]{2}{*}{ Habitat(s) } \\
\hline & & $\begin{array}{l}\text { During boat } \\
\text { surveys }\end{array}$ & $\begin{array}{l}\text { During bank } \\
\text { searches }\end{array}$ & \\
\hline Indian Rock Python ${ }^{+}$ & Python molurus & - & $0.104 \pm 0.031$ & $M, A, F$ \\
\hline Russell's Viper ${ }^{+}$ & Daboia russelii & - & $0.040 \pm 0.011$ & $\mathrm{RC}, \mathrm{A}, \mathrm{F}$ \\
\hline Checkered Keelback $^{+}$ & Xenochrophis piscator & $0.015 \pm 0.006$ & $0.230 \pm 0.055$ & $\mathrm{RC}, \mathrm{RB}, \mathrm{M}, \mathrm{A}$ \\
\hline Indian Rat Snake ${ }^{+}$ & Ptyas mucosas & - & $0.044 \pm 0.011$ & $\mathrm{RB}, \mathrm{A}, \mathrm{F}$ \\
\hline Red Sand $\mathrm{Boa}^{+}$ & Eryx johnii & - & $0.040 \pm 0.008$ & $\mathrm{RB}, \mathrm{A}$ \\
\hline Indian Cobra ${ }^{+}$ & Naja naja & - & $0.011 \pm 0.011$ & $A, F$ \\
\hline Mugger Crocodile & Crocodylus palustris & $0.058 \pm 0.010$ & - & $\mathrm{RC}, \mathrm{I}, \mathrm{RB}, \mathrm{M}$ \\
\hline Gharial & Gavialis gangeticus & - & - & - \\
\hline Black Pond Turtle* & Geoclemys hamiltonii & - & - & - \\
\hline Crowned River Turtle* & Hardella thurjii & - & - & - \\
\hline Red-crowned Roofed Turtle* & Batagur kachuga & - & - & - \\
\hline Three-striped Roofed Turtle* & Batagur dhongoka & - & - & - \\
\hline Brown Roofed Turtle & Pangshura smithii & $1.009 \pm 0.107$ & - & I, RB \\
\hline Indian Roofed Turtle* & Kachuga tecta & - & - & - \\
\hline Indian Tent Turtle* & Pangshura tentoria & - & - & - \\
\hline Indian Black Turtle* & Melanochelys trijuga & - & - & - \\
\hline Indian Flapshell Turtle* & Lissemys punctata & - & - & - \\
\hline Indian Softshell Turtle & Aspideretes gangeticus & $0.052 \pm 0.032$ & - & $\mathrm{RC}, \mathrm{I}, \mathrm{RB}$ \\
\hline Peacock Softshell Turtle & Nilssonia hurum & - & - & I, RB, M \\
\hline Narrow-headed Softshell Turtle* & Chitra indica & - & - & - \\
\hline Monitor Lizard ${ }^{+}$ & Varanus bengalensis & - & $0.134 \pm 0.064$ & $M, A, F$ \\
\hline Common Calotes $^{+}$ & Calotes versicolor & - & $0.276 \pm 0.048$ & I, RB, BC, M, A, F \\
\hline Indian Bull Frog ${ }^{+}$ & Hoplobatrachus tigerinus & - & $0.961 \pm 0.021$ & $\mathrm{I}, \mathrm{RB}, \mathrm{BC}, \mathrm{M}, \mathrm{A}, \mathrm{F}$ \\
\hline
\end{tabular}

*Species reported by Behera (1995) but not recorded in the present surveys; ${ }^{+} \mathrm{New}$ additions to the list

$\mathrm{RC}=$ river course, $\mathrm{I}=$ islands, $\mathrm{RB}=$ riverbeds, $\mathrm{BC}=$ bank cliffs, $\mathrm{M}=$ marshlands, $\mathrm{A}=$ agricultural fields, $\mathrm{F}=$ dense forests along banks

believed the turtle carapace as a sign of protection to their cattle. During our visits to the local fish market (mandi) we also got evidences of illegal fishing (catches $<250 \mathrm{~g}$ ).

\section{Discussion}

The high species richness of the river stretch including species of global significance validates the ecological importance of the area and also merits a need for its conservation and management. Comparisons with earlier reports indicate that our surveys yielded fewer species of birds in contrast to 86 species (Table 2) reported by Behera (1995), but more mammals compared to Behera $(1995,2002)$ including Hog Deer, Swamp Deer, Fishing Cat and Small Indian Civet as new additions (Table 1). We recorded similar number of reptile species in our surveys in comparison with earlier reports of 14 species (12 turtles and two crocodiles) by Behera (2002), but with nine species as new additions (Table 3 ). The probable reasons for fewer bird species encountered may be attributed to seasonal migration in some species which requires a year round sampling effort or cryptic nature of certain species which needs intensive and repetitive surveys for detection, which could not be addressed in this study. The encounter rate for Ganges River Dolphin in the entire stretch was similar to the estimate $(0.23)$ in the Lohit River, eastern Assam (Wakid 2005) but lower than our estimate $(0.52 \pm 0.068)$ for a small stretch of $28 \mathrm{~km}$ between Narora and Anupshahar (Bashir et al. 2010b), 0.44 in the Brahmaputra River, Assam (Mohan et al. 1997) and 1.8 in Vikramshila Gangetic Dolphin Sanctuary (Choudhary et al. 2006). Our results also confirm Brown Roofed Turtle as most abundant turtle 


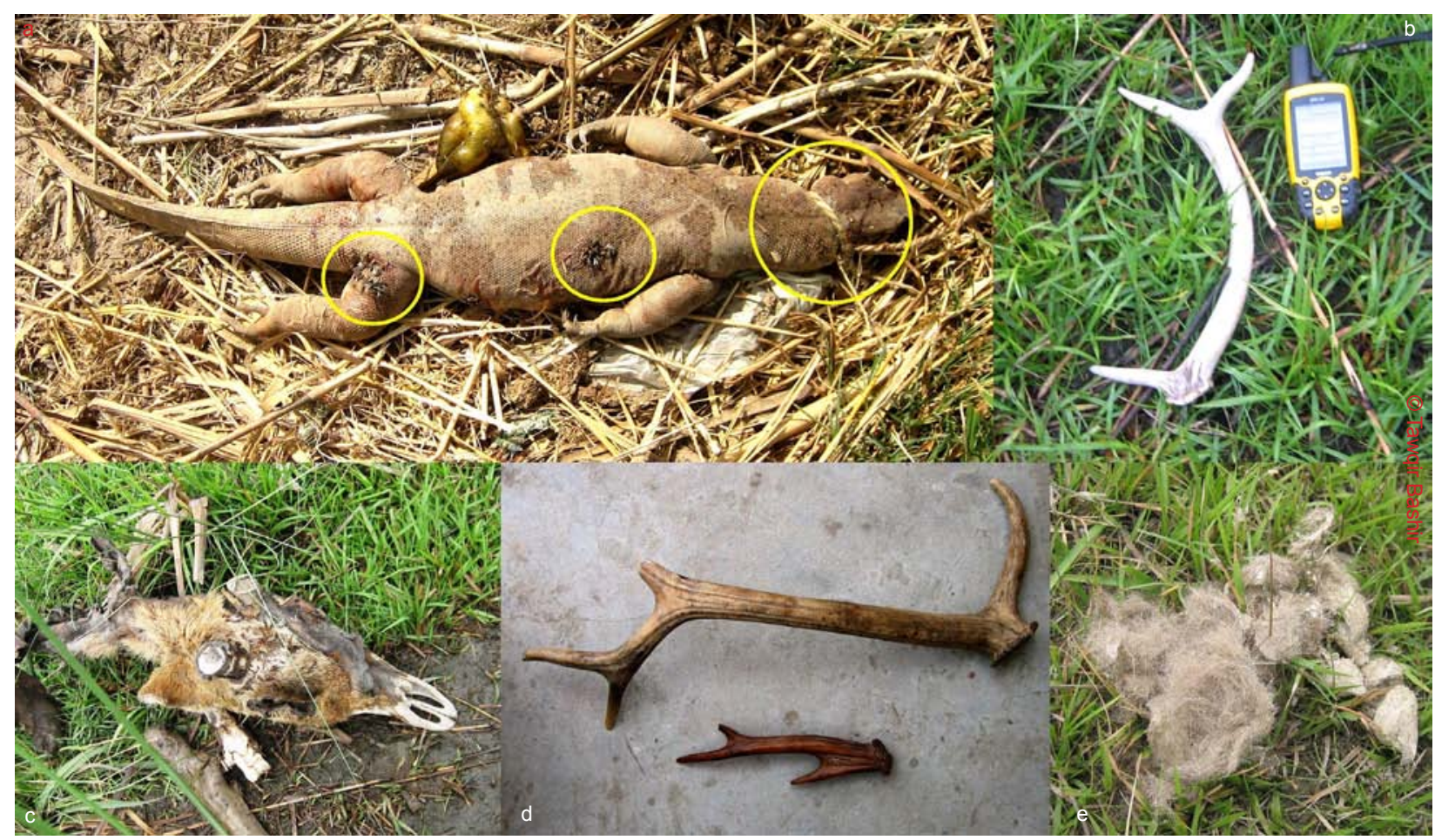

Image 1. (a) Monitor Lizard carcas with deadly wounds; (b) Swamp Deer antler; (c) Swamp Deer carcas with cut antlers; (d) Swamp and Hog deer antlers recovered; (e) Fishing Cat scat

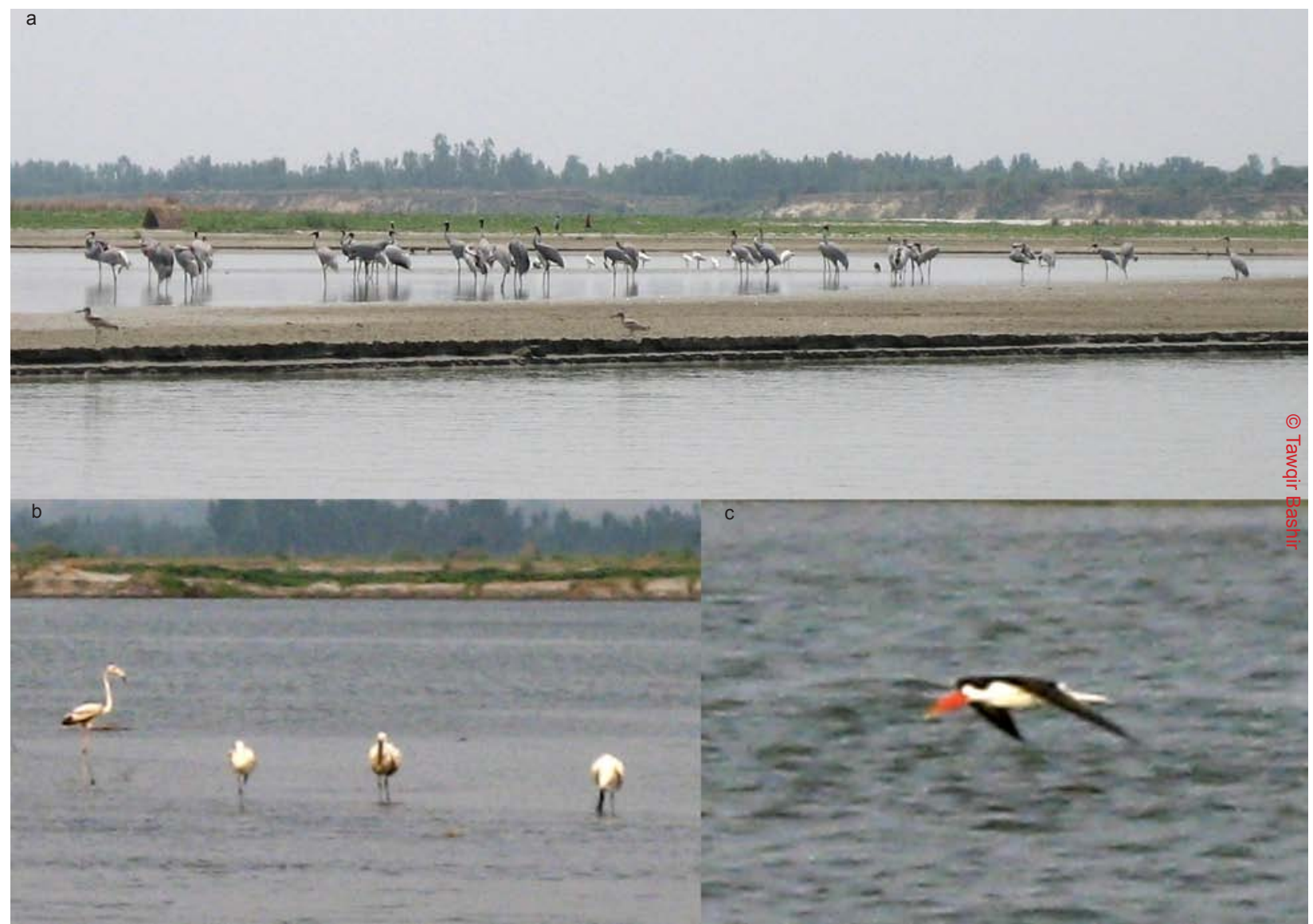

Image 2. (a) Sarus Cranes; (b) Greater Flamingo and Eurasian Spoon Bill; (c) Indian Skimmer 


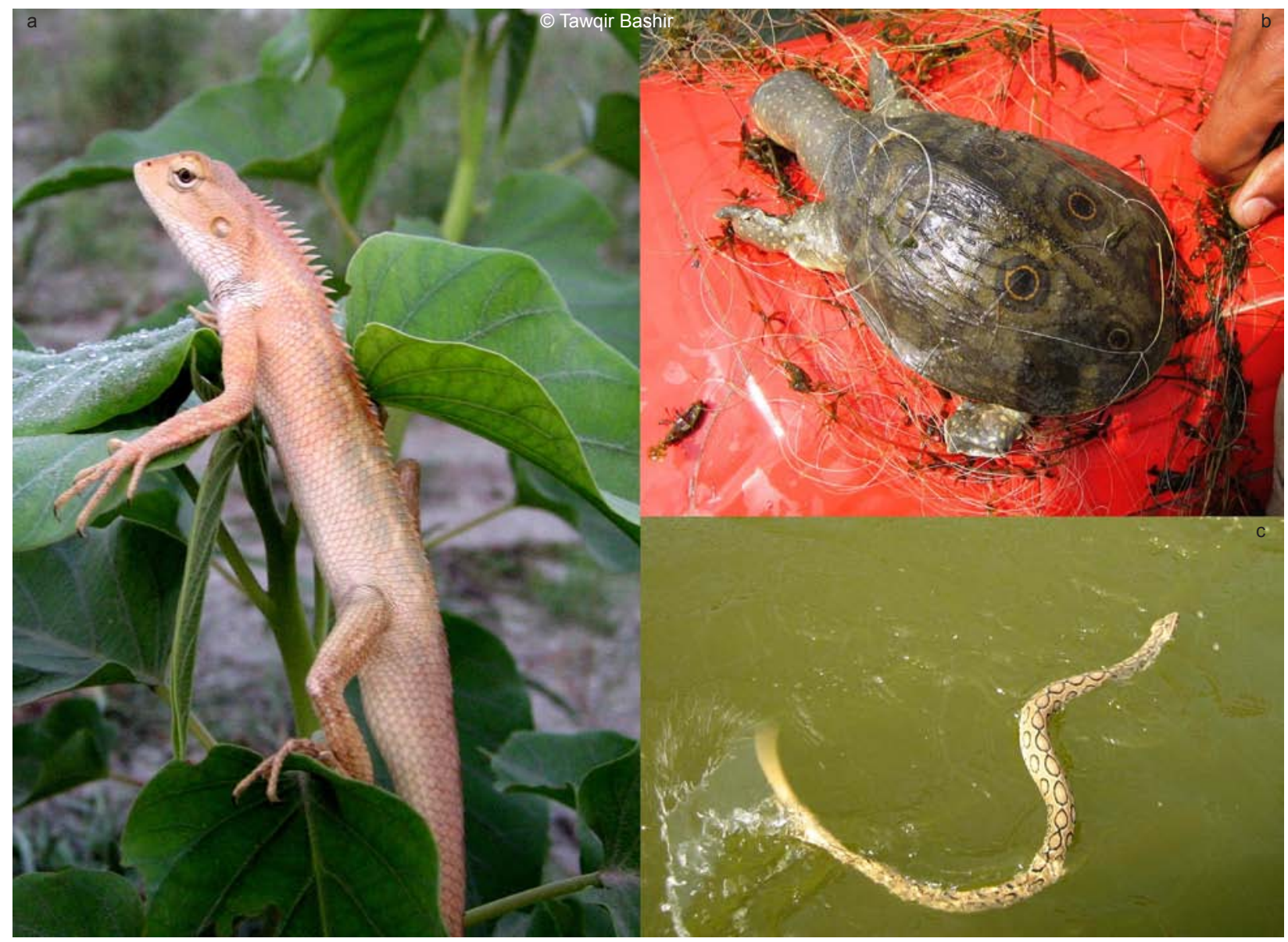

Image 3. (a) Common Calotes; (b) Peacock Softshell Turtle entangled in fishing net; (c) Russell's Viper

species in the stretch as reported earlier (Behera 1995; 2002), signifying it as a potential habitat in the upper Ganges for dolphin and turtle conservation (Behera 1995; Behera \& Rao 1999; Behera 2002). Occurrence of a major proportion of water birds is also an indicator of good habitat quality. Majority of mammal, bird and reptile species occurrences in agricultural fields, forest patches along banks and in marshlands symbolises that not only the river stretch but its banks are equally rich in biodiversity representing a rich riverine ecosystem, but with few concerns; since agricultural activities are continuing to increase along the banks (Bashir et al. 2010a) and additionally some threats to riverine biodiversity were identified at local level in this study. Increasing agricultural activities and percentage of cultivated land of riparian wetlands have been suggested to affect bird communities by decreasing species diversity (Mensing et al. 1998). Despite survey constraints, there is a regular need to assess the level of biodiversity and health of this river stretch. An indicator species approach can be a useful assessment tool in this regard (Anonymous 2008). In a multi-organisimal study of a dynamic ecosystem (wetlands), water birds have been suggested as excellent environmental indicators as their populations are not only extremely dynamic and sensitive to change but more often reflect land use conditions than other groups (Galatowitsch et al. 1999; Anonymous 2008). Hence, future studies should be conducted with this approach along with awareness programs at local levels.

\section{REFERENCES}

Adel, M.M. (2001). Effect on water resources from Upstream Water Diversion in the Ganges Basin. Journal of Environmental Quality 30: 356-368.

Ali, S \& S.D. Ripley (1987). The Compact Handbook of the Birds of India and Pakistan. Oxford University Press, New Delhi, 820pp. 
Anonymous (1998). Inventory methods for colonial-nesting freshwater birds. Standards for Components of British Columbia's Biodiversity No. 8. Ministry of Environment, Lands and Parks Resources Inventory Branch for the Terrestrial Ecosystems Task Force Resources Inventory Committee, 38pp.

Anonymous (2008). Biodiversity Survey of the Integrated Constructed Wetland at Tolka Valley Park. Finglas, Co. Dublin. Dublin City Council. Openfield Ecological Services, 20pp.

Bashir, T., A. Khan, S.K. Behera \& P. Gautam (2010a). Socio-economic factors threatening the survival of Ganges River Dolphin Platanista gangetica gangetica in the upper Ganges River, India. Journal of Threatened Taxa 2(8): 1087-1091.

Bashir, T., A. Khan, P. Gautam \& S.K. Behera (2010b). Abundance and Prey Availability Assessment of Ganges River Dolphin (Platanista gangetica gangetica) in a stretch of Upper Ganges River, India. Aquatic Mammals 36(1): 19-26.

Behera, S.K. (1995). Studies on Population Dynamics, Habitat Utilization and Conservation Aspects of for Gangetic Dolphin (Platanista gangetica) in a stretch of Ganga River from Rishekesh to Kanpur. PhD Thesis, School of Studies in Zoology, Jiwaji University Gawalior, 198pp.

Behera, S.K. \& R.J. Rao (1999). Observation on the behavior of Gangetic Dolphins in the upper Ganga River. Journal of the Bombay Natural History Society 96(1): 43-47.

Behera, S.K. (2002). Status Report of Upper Ganga River (Bijnor to Narora), Ganges River Dolphin Conservation Project, World Wide Fund for Nature- India, 31pp.

Behera, S.K., V. Sagar \& A. Nawab (2008). Environmental flow requirements vis-à-vis habitat use pattern of freshwater dolphins. Proceedings of the 11th International River Symposium, Brisbane, Australia.

Bharati, L., G. Lacombe, P. Gurung, P. Jayakody, C.T. Hoanh \& V. Smakhtin (2011). The impacts of water infrastructure and climate change on the hydrology of the Upper Ganges River Basin. Colombo, Sri Lanka: International Water Management Institute, 36pp. (IWMI Research Report 142), [doi: 10.5337/2011.210].

Carletti, A., De Leo, G.A. \& I. Ferrari (2004). A critical review of representative wetland rapid assessment methods in North America. Aquatic Conservation: Marine and Freshwater Ecosystem 14: 103-113.

Choudhary, S.K., B.D. Smith, S. Dey \& S. Prakash (2006). Conservation and biomonitoring in the Vikramshila Gangetic Dolphin Sanctuary, Bihar, India. Oryx 40(2): 189-197.

Cullen, P. (2003). The Heritage River Proposal - Conserving Australia's undamaged rivers, pp. 513-520. In: Beumer, J.P., A. Grant \& D.C. Smith (eds.). Aquatic Protected Areas: What works best and how do we know? Proceedings of the World Congress on Aquatic Protected Areas, Cairns, Australia - August 2002, University of Queensland Printery, St Lucia, Queensland, Australia.
Das, I. (2002). A Photographic Guide to Snakes and Other Reptiles of India. New Holland Publishers Ltd, London, UK, 144pp.

Dudgeon, D., A.H. Arthington, M.O. Gessner, Zen-Ichiro, Kawabata, D.J. Knowler, C. Le've^que, R.J. Naiman, Anne-He'le'ne Prieur-Richard, D. Soto, M L.J. Stiassny \& C.A. Sullivan (2006). Freshwater biodiversity: importance, threats, status and conservation challenges. Biological Review 81: 163-182.

Dunn, H. (2004). Defining the ecological values of rivers: the views of Australian river scientists and managers. Aquatic Conservation: Marine and Freshwater Ecosystems 14: 413-433.

FISRWG (2001). Stream corridor restoration - principles, processes and practices, adopted as Part 653 of the National Engineering Handbook, USDA-Natural Resources Conservation Service. Available from: http://www.nrcs. usda.gov/technical/stream_restoration/.FederalInteragency Stream Restoration Working Group.

Galatowitsch, S.M., Whited, D.C. \& J.R. Tester (1999). Development of community metrics to evaluate recovery of Minnesota wetlands. Journal of Aquatic Ecosystem Stress and Recovery 6: 217-234.

Georges, A. \& P. Cottingham (eds.) (2002). Biodiversity in inland waters - priorities for its protection and management. Recommendations from the 2001 Fenner Conference on the Environment. Technical Report 1/2002. Cooperative Research Centre for Freshwater Ecology, Canberra, 37pp.

Grimmett, R., C. Inskipp \& T. Inskipp (2001). Pocket Guide to the Birds of the Indian Subcontinent. Oxford University Press, 384pp.

Hawksworth, D.J. \& M.T. Kalin-Arroyo (1995). Magnitude and distribution of biodiversity, pp.107-191. In: V.H. Heywood (ed.). Global biodiversity Assessment, Cambridge University Press, Cambridge, U.K.

IUCN (2010). IUCN Red List of Threatened Species. Version 2010.2. www.iucnredlist.org

Kiszka, J., S. Hassani \& S. Pezeril (2004). Distribution and status of small cetaceans along the French Channel coasts: using opportunistic records for a preliminary assessment. Lutra 47: 33-45.

Menon, V. (2003). Field Guide to Indian Mammals. Dorling Kindersley (India), Penguin Books India, Delhi, 200pp.

Mensing, D.M., S.G. Galatowitsch \& J.R. Tester (1998). Anthropogenic effects on the biodiversity of riparian wetlands of a northern temperate landscape. Journal of Environmental Management 53: 349-377.

Mohan, R.S.L., S.C. Dey, S.P. Bairagi \& S. Roy (1997). On a survey of Ganges River dolphins Platanista gangetica of Brahamputra River, Assam. Journal of the Bombay Natural History Society 94: 483-495.

Myers, N., R.A. Mittermier, C.G. Mittermier, G.A.B. da Fonseca \& J. Kent (2000). Biodiversity hotspots for conservation priorities. Nature 40: 853-858.

Newby, E. (1998). Slowly Down The Ganges. Lonely Planet Publications, 23-25pp. 
Poff, N.L., M.M. Brinson \& J.W. Day (Jr.) (2002). Aquatic ecosystems and global climate change. Technical Report, Pew Center on Global Climate Change, Arlington, USA, 45pp.

Prater, S.H. (1971). The Book of Indian Animals. Bombay Natural History Society, Oxford University Press. Oxford, $324 p p$.

Revenga, C.I., R. Campbell, P. Abell de Villiers \& M. Bryer (2005). Prospecting for monitoring freshwater ecosystems towards the 2010 targets. Philosophical Transactions of the Royal Society B: Biological Sciences 360: 397-413.

Rollfinke, F.B. \& R.H. Yahner (1990). Effects of time of day and season on winter bird counts. Condor 92: 215-219.

Sala, O.E., F.S. Chapin, J.J. Armesto, R. Berlow, J. Bloomfield, R. Dirzo, E. Huber-Sanwald, L.F. Huenneke, R.B. Jackson, A. Kinzig, R. Leemans, D. Lodge, H.A. Mooney, M. Oesterheld, N.L. Poff, M.T. Sykes, B.H. Walker, M. Walker \& D.H. Wall (2000).
Global biodiversity scenarios for the year 2100. Science 287: 1770-1774.

Salemme, E. (2007). “The World's Dirty Rivers". Time. 22 January 2007.

Saunders, D.L., Meeuwig, J.J. \& C.J. Vincent (2002). Freshwater protected areas: strategies for conservation. Conservation Biology 16: 30-41.

Shields, W.M. (1977). The effect of time of day on avian census results. Auk 94: 380-383.

Wakid, A. (2005). Status and distribution of a newly documented residential Gangetic dolphin population in Eastern Assam. Journal of the Bombay Natural History Society 102: 158-161.

Whitaker, R. \& A. Captain (2004). Snakes of India - The Field Guide. Draco Books, Chennai, xiv+481pp.

WWF (2006). Conservation and Management of River Dolphins in Asia. World Wide Fund for Nature, Kathmandu, Nepal. 